\title{
TIME TREND, AGE AND SEX DISTRIBUTION OF DEATHS FROM DIABETES MELLITUS AT THE REGIONAL LEVEL IN THE SLOVAK REPUBLIC
}

\author{
Beáta Gavurová1, Matúš Kubák, Michal Šoltés ${ }^{1}$, Miroslav Barták², Tatiana Vagašová1 \\ ${ }^{1}$ Faculty of Economics, Technical University of Košice, Košice, Slovak Republic \\ 2Department of Addictology, First Faculty of Medicine, Charles University and General University Hospital in Prague, Prague, Czech Republic
}

\section{SUMMARY}

Aim: To describe the time trends, age and sex distribution of death from diabetes mellitus (E10-E14) as a significant part of endocrine, nutritional and metabolic diseases (E00-E90), during 1996-2014 in the Slovak regions, and to estimate the influence of social characteristics on mortality.

Methods: Secondary data on deaths during 1996-2014 were gathered from the National Health Information Center in the Slovak Republic. The total crude death rate per 100,000 of the standard Slovak population and age-standardized death rate per 100,000 of the standard European population were calculated by direct standardization. Multilevel logistic regression analysis was performed.

Results: Deaths from diabetes mellitus account for $91.6 \%$ of deaths registered in the endocrine, nutritional and metabolic diseases Chapter. The age-standardized death rate per 100,000 of inhabitants decreased from 19.2 in 1996 to 15.3 in 2014 in the Slovak Republic, although a massive increase of up to 32.5 was reported in 1999. The highest age-standardized death rates per 100,000 inhabitants were typical for the Košice, Nitra and Trenčín regions. On the other hand, the lowest counts were recorded in the Bratislava region. Mortality from diabetes mellitus starts to be evident in the 45-49 year age-group in both sexes. The median age of death for women is lower in the 75-79 year age-group in comparison to men although the total crude death rate for men in lower age groups is higher. After age 80 the situation is reversed. The odds of dying due to endocrine, nutritional and metabolic diseases decreases by $0.4 \%$ each year. The odds of dying are lower by $17 \%$ and $12.3 \%$, respectively, in the Žilina and Prešov regions compared to Bratislava region. Women have a higher probability of dying by $38 \%$ in contrast to men, and married couples by $16.7 \%$ than singles. Age is proved to be an insignificant factor.

Conclusions: In spite of the declining trend of mortality from diabetes mellitus, it is necessary to reduce the risk of its incidence by healthier food consumption and physical activity.

Key words: diabetes mellitus, mortality, age distribution, Slovak regions

Address for correspondence: M. Kubák, Faculty of Economics, Technical University of Košice, Němcovej 32, 04001 Košice, Slovak Republic, E-mail: matus.kubak@tuke.sk

https://doi.org/10.21101/cejph.a5052

\section{INTRODUCTION}

Some diseases have occurred breakthroughs, which meant a major turning point in the treatment of the diseases and their preventions. Unfortunately, other diseases are still resistant. Diabetes mellitus is a disease that has overcome enormous development of knowledge, from the explanation of the mechanism to various therapeutic approaches and technologies. New findings bring further questions, opens up the need for further investigation and lead to doubts $(1,2)$.

Diabetes mellitus is a chronic disease which results in high morbidity, disability and mortality. The number of diabetics in the world is growing, which brings serious problems not only in terms of health care, but also from the economic point of view $(2,3)$. Therefore, diabetes mellitus is known as epidemic in the 21st century all around the world and its increase in population is alarming. According to statistical data, it occurred over the last 20 years to a doubling number of registered diabetics in developed countries (3-6).
According to the International Diabetes Federation, 409,200 cases of diabetes mellitus were registered at diabetic ambulances in Slovakia in 2015 (7-9). In the long-time approach, the number of diabetics in Slovak population as well as in other countries is growing. Most diabetics are registered at medical facilities in Bratislava region (a total of 54,285 persons), minimum in Žilina region (32,262 people) in 2015 (10). If the V4 countries are taken into consideration, a high number of people suffering from diabetes prevail in the Czech Republic. According to the Institute of Health Information and Statistics of the Czech Republic, almost 862,000 patients were treated from diabetes mellitus in 2013 in the Czech Republic (11). However, in 2015 there were more than 799.300 cases of diabetes (12). In Hungary, 694,700 cases of diabetes were recorded (13) and in Poland over 2.2 million cases in 2015 (14).

\section{Diabetes Mellitus by Sex and Age}

There are some studies that confirm increasing mortality from diabetes mellitus with age and varying by sex. Roper et al. (15) 
found out that life expectancy both of men and women diagnosed at the age of 40 , is reduced by 8 years in people without diabetes, but in case of women the number may be even lower. Similarly, both sexes with diabetes have shown higher mortality than people without diabetes, while level of mortality by diabetes depends on the studied region.

Population mortality due to diabetes mellitus varies according to age. The human and economic impact of diabetes is huge for all ages, especially with regard to elderly people. Generally, every year approximately 4.6 million of citizens die because of this disease and half of those people are over 60 years. This is one of the reasons why diabetes mellitus belongs to the top ten causes of disability worldwide. In this time, the diabetes epidemic and the ageing effect around the world are growing faster (15-17).

In many developed countries, diabetes differs by gender where number of incidence of diabetes is comparable to the average values observed worldwide $(5,18,19)$ and indicating the need to take the socioeconomic and gender gap into account when developing policies in the field of public health (18).

Type 2 diabetes represents the highest share, approximately $90 \%$, within a diabetic syndrome. Type 2 diabetes affects approximately $5-7 \%$ of the population of developed region, while $60-80 \%$ of these patients are also overweight and obese. Negative is the lack of exercise, thus inactivity $(3,17)$. According to recent study of Scotland, incidence of type 2 diabetes has stabilized in recent years (21). On the other hand, Harjutsalo et al. (17) emphasized that despite considerable advances in diabetes care, type 1 diabetes is still associated with serious premature mortality resulting from acute and chronic complications of diabetes. Prevention of diabetes remains important and significant, in particular among socio-economically deprived populations.

At present, development of diabetes has a rising trend and is affected by many genetic factors, but also by socio-economic characteristics. In addition to high number of diabetics, the development of chronic complications of this disease impairs the quality of life or shortens its duration (3, 21-23).

As reported by the WHO, statistics confirm the increase of the diabetes disease in all ages, mainly due to obesity, unhealthy diets and lack of physical activity. Worldwide, there are currently 415 million people with diabetes and this number will rise to 642 million in 2040 (24, 25). WHO has identified obesity as a serious civilization disease (26). Obesity represents a risk factor for non-communicable diseases, especially in connection with diabetes due to its high and continuously rising incidence (3, 21, 26-28). On the other hand, cardiovascular diseases are the most common cause of mortality among patients with diabetes. At least $65 \%$ of patients with type 2 diabetes die from cardiovascular disease $(4,15)$.

There exist many other research studies of diabetes mellitus that are described in the next literature review section.

\section{Literature Review}

Table 1 provides a summary of selected research studies (2938 ) in recent years that examined the morbidity and mortality from diabetes mellitus and its medical and socioeconomic causal links. The studies are in terms of scope, procedural practices in research, as well as they are monitoring the heterogeneous determinants. This fact is determined by the objectives of the research and its orientation of specific research teams from either university or clinical sphere. Although, many studies on socio-economic factors are not explicitly monitored, their importance is secondary and recovered mainly in the interpretative lines. Duration of diabetes and also the age of patient play an important role in the prediction process, as well as the impact of co-morbidities (cardiovascular and other diseases). However, a minimum attention is paid to this factor, because of methodological problems of the measurement and quantification. The examination of the healing process and its causal links, as well as dietary habits and lifestyle are receiving attention in some studies. As demonstrated by the results of the presented research studies, heterogeneity factors affecting mortality and morbidity of diabetes require a broader multi-dimensional research into the diagnosis and examination of all causalities related to them. This requires access to quality, more structured data in databases on the national registers or from clinics and research centers. This creates a platform for national and international comparison and improvement of prediction processes to make high-quality programs of prevention and eliminate health inequalities.

\section{MATERIALS AND METHODS}

The analysis focused on dataset containing the total mortality rate in the Slovak Republic within period 1996-2014. In the descriptive part of the paper, a description of evolution of diseases comprised in the chapter Endocrine, nutritional and metabolic diseases (E00-E90) of the International Classification of Diseases in the Slovak Republic during mentioned period is offered. In quantitative analysis, where multilevel logistic regression was used, the main focus was put on model comprising dichotomous outcome variables. In a presented model, the log odds of dying due to the Endocrine, nutritional and metabolic diseases against dying from all other possible diseases is modeled as a linear combination of the predictor variables. Predictor variables are year of death, age, gender, region of death, and marital status.

\section{RESULTS AND DISCUSSION}

Within the period of 1996-2014, 14,442 people died because of Endocrine, nutritional and metabolic diseases (E00-E90) in the Slovak Republic. It counts for $1.4 \%$ of all diseases in the mentioned period. The International Classification of Diseases issued by the World Health Organization, which is used as the standard diagnostic tool, was used in this analysis. Table 2 shows how individual diagnosis within the chapter Endocrine, nutritional and metabolic diseases (E00-E90) participated on total number of deaths caused by diagnosis. The data have been provided by the National Health Information Center of the Slovak Republic.

Vast majority of deaths has been caused by Diabetes mellitus (E10-E14). In total, 13.228 deaths have been caused by Diabetes mellitus. It equals to $91.6 \%$ of deaths within the chapter. Another dangerous group of diseases is group of Metabolic disorders, where 918 deaths were observed, what stands for $6.4 \%$ of all deaths within the chapter of Endocrine, nutritional and metabolic diseases. Other groups of diseases participated with less than $1 \%$ of total deaths within the chapter. The following analysis focuses 
Table 1. Literature review

\begin{tabular}{|c|c|c|c|}
\hline Source & Aim & Methods & Results \\
\hline Shi et al. (2016) & $\begin{array}{l}\text { Explore the link between impaired } \\
\text { glucose tolerance (IFG)/type } 2 \\
\text { diabetes and mortality, and also } \\
\text { examine any interaction with the } \\
\text { model of food intake in the Chinese } \\
\text { population. }\end{array}$ & $\begin{array}{l}2,849 \text { Chinese adults aged } 20 \text { and } \\
\text { over for } 10 \text { years. Factor analysis } \\
\text { used to calculate dietary patterns. } \\
\text { Hazards ratio calculated based on } \\
\text { Cox proportional hazards analysis } \\
\text { and competition risks regression. }\end{array}$ & $\begin{array}{l}\text { IFG and diabetes are associated with a significantly } \\
\text { increased risk of death among Chinese adults. Dietary } \\
\text { patterns associated with high intake of vegetables was } \\
\text { associated with a decreased risk of mortality among } \\
\text { individuals with IFG and diabetes. }\end{array}$ \\
\hline $\begin{array}{l}\text { Sjöberg et al. } \\
\text { (2016) }\end{array}$ & $\begin{array}{l}\text { Consider the relationship between } \\
\text { the parity and mortality in adults with } \\
\text { childhood onset of type } 1 \text { diabetes. }\end{array}$ & $\begin{array}{l}\text { Mortality and reproduction data of } \\
308,617 \text { person-years in Finland. Of } \\
\text { the 2,307 men and 2,819 women } \\
\text { with type } 1 \text { diabetes. All persons } \\
\text { having diagnosed diabetes at age } 17 \\
\text { and less in the years } 1965-1979 .\end{array}$ & $\begin{array}{l}\text { The link between mortality and parity as a different } \\
\text { pattern in men and women with type } 1 \text { diabetes. We can- } \\
\text { not tell to what extent this reflects the impact of health } \\
\text { decisions about family planning for people with type } 1 \\
\text { diabetes without further studies. }\end{array}$ \\
\hline Wan et al. (2016) & $\begin{array}{l}\text { To examine the relationship } \\
\text { between the variation in HbA1c } \\
\text { and the incidence of cardiovascular } \\
\text { disease (CVD) and mortality of Chi- } \\
\text { nese patients with type } 2 \text { diabetes } \\
\text { (T2DM) of the primary care. }\end{array}$ & $\begin{array}{l}\text { A retrospective cohort study of } \\
91,866 \text { patients with T2DM aged } \\
\text { equal or more than } 18 \text { years with no } \\
\text { previous history of CVD. Measured } \\
\text { by the standard deviation, Cox } \\
\text { proportional hazards regression } \\
\text { analysis. }\end{array}$ & $\begin{array}{l}\text { Variability of } \mathrm{HbA} 1 \mathrm{c} \text { regardless of the medium level } \\
\text { of } \mathrm{HbA} \mathrm{C} \text { can provide value added information as a } \\
\text { potential predictor for development of CVD and mortal- } \\
\text { ity among patients with diabetes, especially in older } \\
\text { patients. }\end{array}$ \\
\hline $\begin{array}{l}\text { Campmans- } \\
\text { Kuijpers et al. } \\
(2015)\end{array}$ & $\begin{array}{l}\text { Examine the relation between the } \\
\text { intake of carbohydrates and isoca- } \\
\text { loric compensation comprising (i) } \\
\text { the total fat, (ii) saturated fatty acids } \\
\text { (SFA), (iii), mono-unsaturated fatty } \\
\text { acids (MUFA), and (iv) fatty acids } \\
\text { polyunsaturated (PUFA) to any CVD } \\
\text { causes of mortality in patients with a } \\
\text { change in weight of type } 2 \text { diabetes. }\end{array}$ & $\begin{array}{l}\text { 6,192 patients with type } 2 \text { diabetes. } \\
\text { Cox linear regression. }\end{array}$ & $\begin{array}{l}13 \% \text { of participants died, } 4 \% \text { out of them from CVD. Total } \\
\text { carbohydrate replacement by fats has been associated } \\
\text { with higher total risk of death, and SFA associated with } \\
\text { higher CVD mortality. Lower risk of death was when } \\
\text { replacing carbohydrates for MUFA and it was also as- } \\
\text { sociated with a reduction in weight. Instead of promoting } \\
\text { carbohydrate substitutes for total fat, the recommenda- } \\
\text { tions should be to weaken the substitutes for fat subtypes } \\
\text { of SFA and MUFA. }\end{array}$ \\
\hline $\begin{array}{l}\text { Huang et al. } \\
(2014)\end{array}$ & $\begin{array}{l}\text { Different rates of diabetes complica- } \\
\text { tions and mortality across age and } \\
\text { duration of diabetes }\end{array}$ & $\begin{array}{l}2004-2010 \text {; it includes } 72,310 \text { peo- } \\
\text { ple older or equal to } 60 \text { and patients } \\
\text { of type } 2 \text { diabetes. }\end{array}$ & $\begin{array}{l}\text { Duration of diabetes and advancing age independently } \\
\text { predict morbidity and mortality due to diabetes. For long- } \\
\text { term survival with increasing diabetes and increasing } \\
\text { age of the population further research and public health } \\
\text { impacts to reduce hypoglycemia to complement ongoing } \\
\text { efforts to reduce CVD and vascular complications are } \\
\text { needed. }\end{array}$ \\
\hline $\begin{array}{l}\text { Morimoto et al. } \\
\text { (2013) }\end{array}$ & $\begin{array}{l}\text { Examine specific long-term mortality } \\
\text { trends for patients diagnosed with } \\
\text { type } 1 \text { diabetes in childhood in } \\
\text { Japan. }\end{array}$ & $\begin{array}{l}\text { Individuals diagnosed with type } 1 \\
\text { diabetes aged less than or equal to } \\
18 \text { between } 1965 \text { and } 1979 \text {. Com- } \\
\text { paring the status of death or survival } \\
\text { till January } 1,2005 \text { and distributed } \\
\text { causes of death into pertaining } \\
\text { categories. }\end{array}$ & $\begin{array}{l}\text { In Japan, individuals with type } 1 \text { diabetes diagnosed in } \\
\text { childhood, and with duration of } 20 \text { years, the CVD has } \\
\text { been the leading cause of death similar to the white race. } \\
\text { The longer the duration of diabetes was, the more atten- } \\
\text { tion should be paid to the prevention of CVD. }\end{array}$ \\
\hline Liu (2011) & $\begin{array}{l}\text { To examine independent and } \\
\text { joint effects of the lack of social } \\
\text { ties (LSC) and diabetes mellitus } \\
\text { on the riskiness of death among } \\
\text { older white Americans and African- } \\
\text { Americans. } \\
\end{array}$ & $\begin{array}{l}\text { Data used from the study: Second } \\
\text { Longitudinal Study of Aging score } \\
\text { LSC to measure social ties created. }\end{array}$ & $\begin{array}{l}\text { LSC mortality risk similar to diabetes. Both of these } \\
\text { factors are independent forecasts of death among adult } \\
\text { white Americans and African-Americans. In addition to } \\
\text { controlling disease risk factors, improved social relation- } \\
\text { ships can bring new insights to reduce the mortality of } \\
\text { the elderly. }\end{array}$ \\
\hline $\begin{array}{l}\text { Feltbower et al. } \\
(2008)\end{array}$ & $\begin{array}{l}\text { To examine mortality and causes of } \\
\text { death in individuals diagnosed with } \\
\text { type } 1 \text { diabetes aged less or equal } \\
\text { to } 29 \text {. }\end{array}$ & $\begin{array}{l}\text { Comparison of registered individuals } \\
\text { diagnosed with type } 1 \text { diabetes with } \\
\text { mortality registers. }\end{array}$ & $\begin{array}{l}\text { Patients diagnosed with type } 1 \text { diabetes under the age of } \\
30 \text { years had } 4.7 \text { times higher risk of death. Almost half } \\
\text { of the deaths were caused by acute or chronic complica- } \\
\text { tions of diabetes. Deaths due to wrong use of drugs may } \\
\text { be a new trend in this population and require further } \\
\text { study. }\end{array}$ \\
\hline $\begin{array}{l}\text { Pavkov et al. } \\
(2006)\end{array}$ & $\begin{array}{l}\text { Compare the incidence of diabetes } \\
\text { with end-stage renal disease } \\
\text { (ESRD) and mortality among Pima } \\
\text { Indians with type } 2 \text { diabetes in youth } \\
\text { or delayed onset. }\end{array}$ & $\begin{array}{l}\text { The mortality rate of individuals aged } \\
22-55 \text { years according to age at } \\
\text { diagnosis of type } 2 \text { diabetes. }\end{array}$ & $\begin{array}{l}\text { Early onset of type } 2 \text { diabetes is associated with a signifi- } \\
\text { cantly higher incidence of ESRD and mortality in middle } \\
\text { age. Longer duration of type } 2 \text { diabetes in middle age in } \\
\text { individuals diagnosed with diabetes aged less than } 20 \\
\text { years largely brings these results. }\end{array}$ \\
\hline
\end{tabular}

Continued on next page 
Continued from previous page

\begin{tabular}{|l|l|l|l|}
\hline Source & Aim & Methods & Results \\
\hline $\begin{array}{l}\text { Soedamah-Muthu } \\
\text { et al. (2006) }\end{array}$ & $\begin{array}{l}\text { Construction of estimates of abso- } \\
\text { lute and relative risk of all-cause } \\
\text { death among patients with type 1 } \\
\text { diabetes in the UK. }\end{array}$ & $\begin{array}{l}\text { Selection of patients with type 1 } \\
\text { diabetes and comparison with non- } \\
\text { diabetic subjects since January 1992 } \\
\text { to1999. }\end{array}$ & $\begin{array}{l}\text { Despite advances in charge of mortality in Great Britain } \\
\text { over the last decade it continues to be much higher } \\
\text { among patients with type 1 diabetes than among those } \\
\text { without diabetes. }\end{array}$ \\
\hline
\end{tabular}

Table 2. Endocrine, nutritional and metabolic diseases (EOO-E90) - overall mortality

\begin{tabular}{|c|c|c|}
\hline Type of diagnosis & Frequency & Percent \\
\hline Disorders of thyroid gland (E00-E07) & 102 & 0.7 \\
\hline Diabetes mellitus (E10-E14) & 13,228 & 91.6 \\
\hline Other disorders of glucose regulation and pancreatic internal secretion (E15-E16) & 38 & 0.3 \\
\hline Disorders of other endocrine glands (E20-E35) & 39 & 0.3 \\
\hline Malnutrition (E40-E46) & 77 & 0.5 \\
\hline Other nutritional deficiencies (E50-E64) & 27 & 0.2 \\
\hline Obesity and other hyperalimentation (E65-E68) & 13 & 0.1 \\
\hline Metabolic disorders (E70-E90) & 918 & 6.4 \\
\hline Total & 14,442 & 100.0 \\
\hline
\end{tabular}

on Diabetes mellitus (E10-E14) as a main cause of deaths within Endocrine, nutritional and metabolic diseases (E00-E90).

Figure 1 depicts the average age of death in the regions due to a specific group of diseases within chapter Endocrine, nutritional and metabolic diseases (E00-E90) within total monitored period. Diabetes mellitus (E10-E14) causes deaths in relatively young senior age and this age is perfectly stable across regions. Another interesting fact is that Disorders of other endocrine glands (E20-E35) have very diverse manifestation across the regions. Malnutrition (E40-E46) seems to be problematic for young inhabitants in Prešov region, Košice region and Trenčín region. On the other hand, Malnutrition (E40-E46) causes deaths of elderly persons in Bratislava region, Trnava region, Nitra region and Žilina region. Metabolic disorders (E70-E90) seem to have homogenous manifestation across the regions.
Figure 2 shows the evolution of age-standardized death rate per 100,000 of inhabitants in the Slovak Republic. The figure indicates, that mortality rate dramatically increased within the period of 1996-1999, from 19.2 to 32.5 per 100,000 of inhabitants. Therefore, the mortality rate of Diabetes mellitus (E10-E14) permanently decreases on 15.3 per 100,000 of inhabitants in 2014 . The figure also indicates that the male mortality rate is slightly higher than females' one.

Figure 3 provides a brief overview of the situation within a group of Diabetes mellitus (E10-E14) during the whole period. Type 1 diabetes mellitus (E10) causes deaths in younger age in all regions comparing to Type 2 diabetes mellitus. In general, compared to all diseases within the group, Type 2 diabetes mellitus (E11) causes deaths in late age. The only exception is Other specified diabetes mellitus (E13) in Trnava region, where

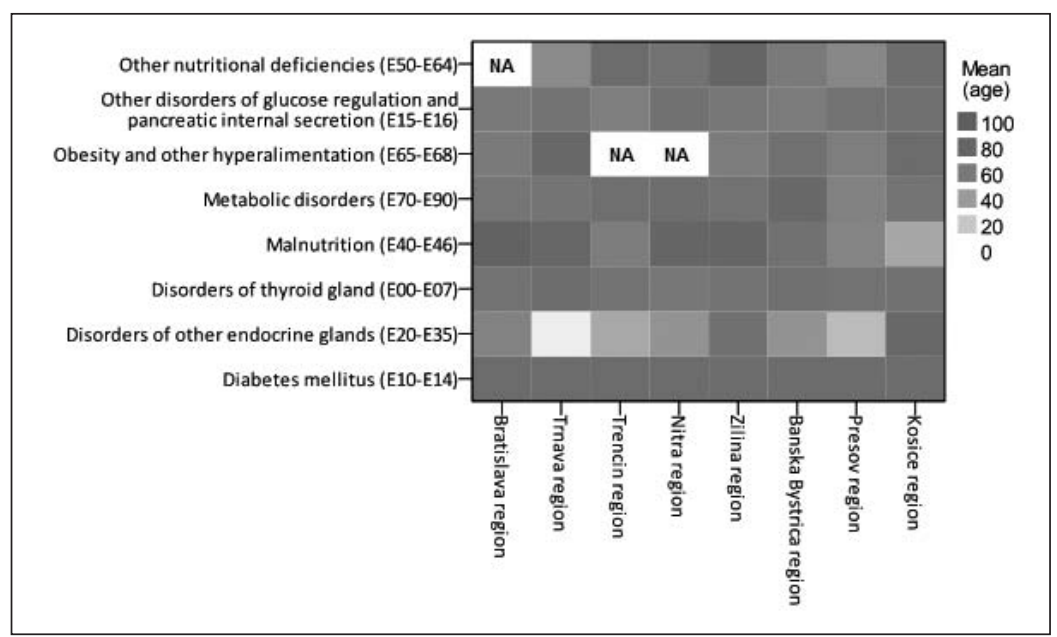

Fig. 1. Spatial distribution of average age of death.

NA - not available 


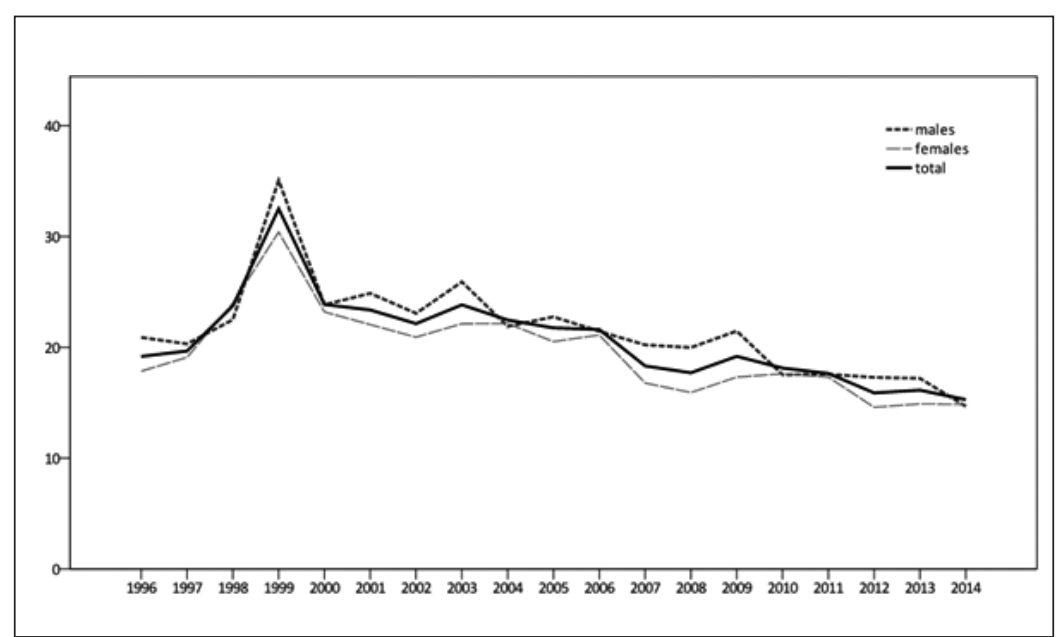

Fig. 2. Age-standardised death rate per 100,000 inhabitants by years.

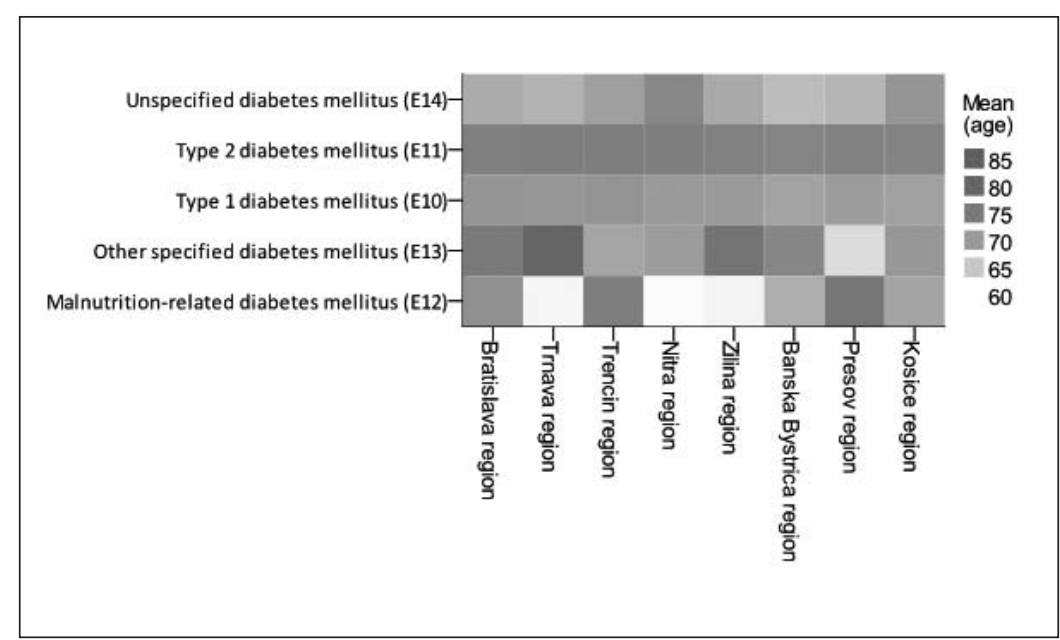

Fig. 3. Spatial distribution of average age of death within Diabetes mellitus (E10-E14).

age of deaths is much higher compared to other diseases within the group.

Figure 4 proposes the spatial distribution of age-standardized death rate per 100,000 of inhabitants according to the European standard population by sex. The worst situation is in Košice region, Nitra region and Trenčín region. On the other hand, the smallest death rate is in Bratislava region, Prešov region and Trnava region. Concerning differences between sexes, the biggest ones are in the Banská Bystrica region, Bratislava region, Košice region and Prešov region. Slight differences in terms of sex are in Nitra region and Trnava region. Moderate differences between sexes are in Trenčín region and Žilina region.

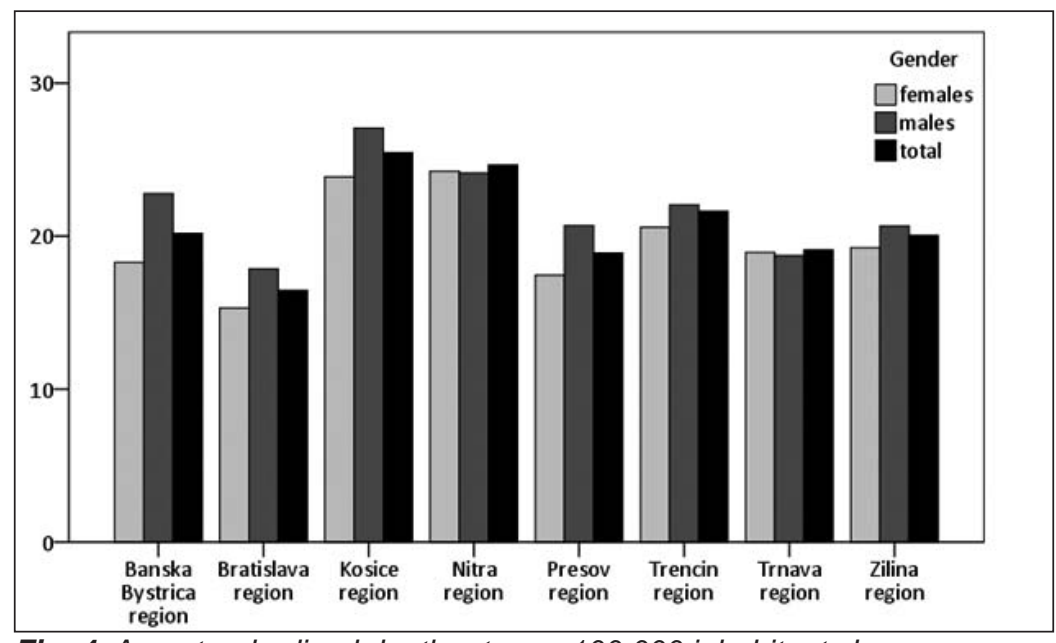

Fig. 4. Age-standardised death rate per 100,000 inhabitants by sex. 
Figure 5 is resuming the evolution of Diabetes mellitus (E10E14) age-standardized death rate per 100,000 of inhabitants by region within the period of 1996-2014. Apparent decrease in mortality rate is visible only in the Banská Bystrica region, Košice region, Nitra region, Prešov region, Trenčín region and Žilina region. In Bratislava region and Trnava region, the reduction of mortality rate related to Diabetes mellitus is not evident (E10-E14).

Figure 6 depicts the situation concerning deaths by Diabetes mellitus (E10-E14), while using box-plots within the period of 1996-2014. Diabetes mellitus (E10-E14) starts to be problem in terms of mortality in the age category of 45-49. Since this age, the increments in mortality are obvious. An interesting fact is that females' median death age is lower until the age category of 75-79 in comparison to males' one (dark line in the boxes).
Also the boxes are thinner than those of males, thus dispersion of observations is smaller. Approximately $50 \%$ of observations should be situated within the boxes, when data are normally distributed. From age category of 80-84, females' median age is higher in comparison to males' one. Moreover, the T-bars are wider in the case of females, what indicates that death age varies more for females than for males. In all death categories, few outliers are evident that indicates well distribution of data in the individual age intervals.

Figure 7 points out the difference between sexes in terms of total crude death rate per 100,000 of inhabitants during whole period of 1996-2014. It is obvious that the mortality rate is higher for males until age category of 75-79. From this point, the female mortality rate starts to be significantly higher than males' one.
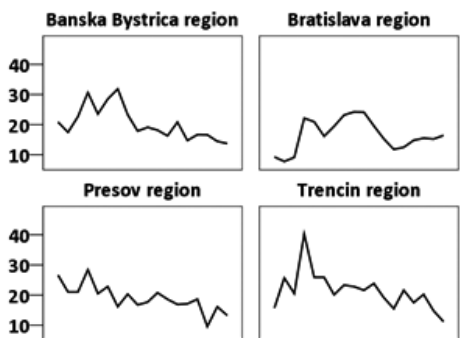

Trencin region

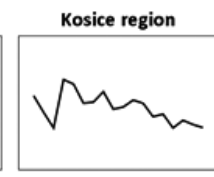

Trnava region
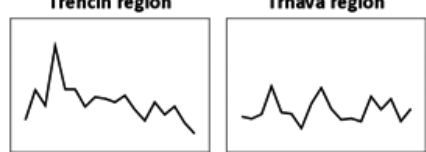

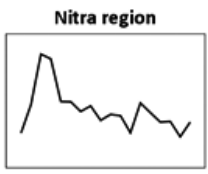

Zilina region

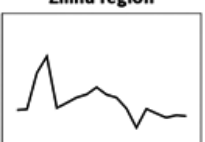

Fig. 5. Age-standardised death rate per 100,000 inhabitants by region (1996-2014).

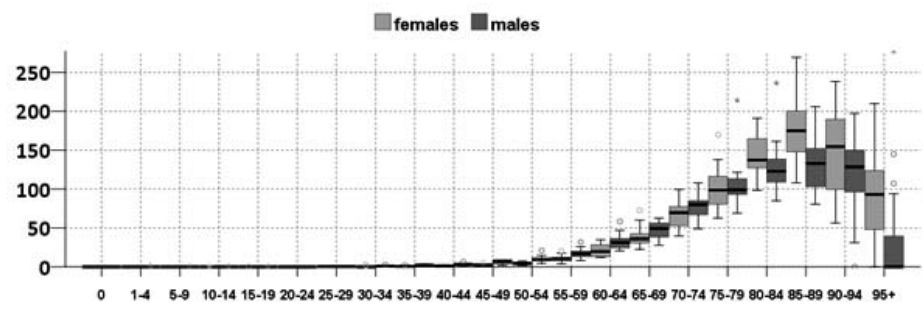

Fig. 6. Age-standardised death rate per 100,000 inhabitants by sex and age category.

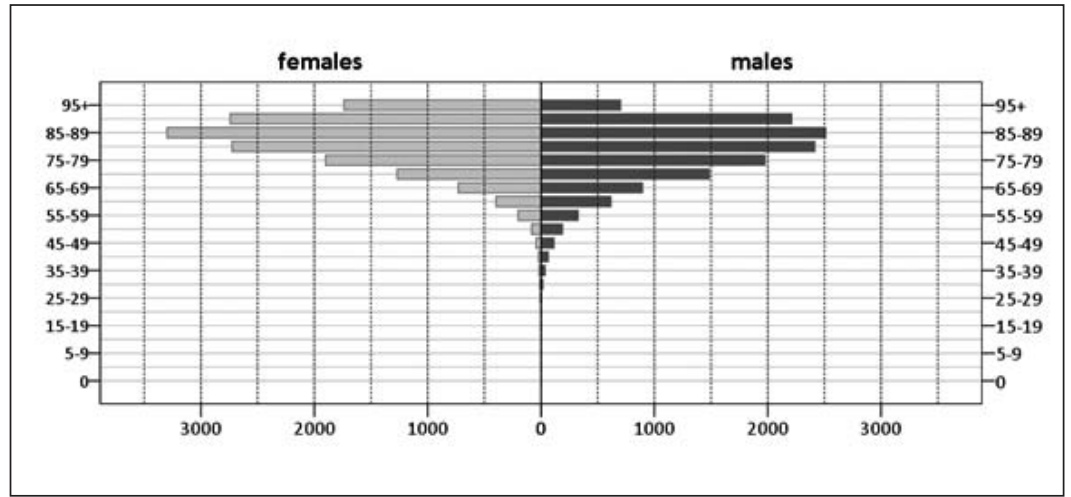

Fig. 7. Sum of crude death rate per 100,000 inhabitants (1996-2014). 
Table 3. Output of multilevel logistic model

\begin{tabular}{|c|c|c|c|c|c|c|}
\hline & B coefficient & Standard error & Wald & $\begin{array}{l}\text { Degrees } \\
\text { of freedom }\end{array}$ & $p$-value & Odds ratio \\
\hline Year & -0.004 & 0.001 & 15.566 & 1 & $<0.001$ & 0.996 \\
\hline Age & 0.000 & 0.000 & 0.685 & 1 & 0.408 & 1.000 \\
\hline Region & & & 130.769 & 7 & $<0.001$ & \\
\hline Trnava & -0.073 & 0.026 & 8.019 & 1 & 0.005 & 0.929 \\
\hline Trenčín & -0.073 & 0.026 & 8.200 & 1 & 0.004 & 0.929 \\
\hline Nitra & 0.014 & 0.023 & 0.368 & 1 & 0.544 & 1.014 \\
\hline Žilina & -0.186 & 0.026 & 52.444 & 1 & $<0.001$ & 0.830 \\
\hline Banská Bystrica & 0.030 & 0.024 & 1.557 & 1 & 0.212 & 1.030 \\
\hline Prešov & -0.132 & 0.025 & 27.533 & 1 & $<0.001$ & 0.877 \\
\hline Košice & -0.070 & 0.024 & 8.426 & 1 & 0.004 & 0.932 \\
\hline Gender-females & 0.322 & 0.013 & 573.025 & 1 & $<0.001$ & 1.380 \\
\hline Marital status & & & 67.804 & 3 & $<0.001$ & \\
\hline Married & 0.154 & 0.023 & 43.445 & 1 & $<0.001$ & 1.167 \\
\hline Divorced & 0.051 & 0.031 & 2.799 & 1 & 0.094 & 1.053 \\
\hline Widowed & 0.065 & 0.025 & 6.507 & 1 & 0.011 & 1.067 \\
\hline Constant & 5.033 & 2.229 & 5.098 & 1 & 0.024 & 153.388 \\
\hline
\end{tabular}

Bratislava region is reference category for region.

Single people are reference category for marital status.

\section{Multilevel Logistic Regression}

Multilevel logistic regression was run to study possible influence of socio-demographic factors on odds of dying, because of Endocrine, nutritional and metabolic diseases (E00-E90). Dependent variable in the model is a cause of death, a dichotomic variable that obtains value 1 , if cause of death is disease listed in chapter Endocrine, nutritional and metabolic diseases (E00-E90) and value 0 , if cause of death is from another Chapter of International Statistical Classification of Diseases and Related Health Problems. Explanatory variables are: year of death, age, region of death, sex and marital status. Table 3 contains the output of our multilevel logistic model.

The odds of dying, due to Endocrine, nutritional and metabolic diseases, decrease year by year by $0.4 \%$. This chance is yearly reduced only with respect to other causes of deaths. The striking fact is that age is not statistically significant variable in the model. Age is not relevant in reference to other causes of death. Concerning the regional aspect, where Bratislava region was set as a contrast variable, findings are following: the odds of dying because of Endocrine, nutritional and metabolic diseases are lower by $7.1 \%$ in Trnava and Trenčín regions compared to Bratislava region. For Nitra region and Banská Bystrica region the coefficients are not statistically significant. The odds of dying because of Endocrine, nutritional and metabolic diseases are lower by $17 \%$ in Žilina region, by $12.3 \%$ in Prešov region and by $6.8 \%$ in Košice region compared to Bratislava region. The odds of dying because of Endocrine, nutritional and metabolic diseases are by $38 \%$ higher for females compared to males. Married individuals have by $16.7 \%$ bigger chance to die because of Endocrine, nutritional and metabolic diseases than single ones. The odds of dying because of Endocrine, nutritional and metabolic diseases are by $6.7 \%$ higher for widowed people than for single people. In case of divorced people, the coefficient is not statistically significant. Presented coefficients and findings have to be taken into account with the fact that several variables at once were controlled and with respect to other causes of deaths.

\section{CONCLUSIONS}

In conclusion, the analysis revealed the declining trend of diabetes mellitus mortality rates what is in contrast to the WHO statement about the increasing incidence of diabetes worldwide. According to WHO, the reasons of an increase are excessive consumption of food and beverages with high share of sugar. Daily routines need to be re-considered: eating healthier, be physically active and avoid excessive weight gain, which is one of the high risk factors causing this disease. According to most experts, diabetes can be prevented by applying healthy living standards that should be encouraged by legislators to support opportunities to increase quality of life.

\section{Acknowledgements}

This work was supported by the VEGA project No. 1/0945/17 Economic research on quantification of marketing processes aimed at improving value for patient, multidimensional analyses of the marketing mix of healthcare facilities and quantification of their importance in the process of establishment of the system to measure the quality and efficiency in healthcare of the Slovak Republic.

\section{Conflict of Interest}

None declared. 


\section{REFERENCES}

1. Škrha K. Diabetology or how it starts and ends. Prague: Maxdorf; 2014. (In Czech.)

2. Štechová K, Perušičová J, Honka M. Type 1 diabetes mellitus. Prague: Maxdorf; 2014. (In Czech.)

3. Olšovský J. Type 2 diabetes mellitus. Prague: Maxdorf; 2012. (In Czech.)

4. Pella D. Pitfalls of diabetes and possible minimization. Bratislava: Mafra Slovakia; 2016. (In Slovak.)

5. Polakowska M, Piotrowski W. Incidence of diabetes in the Polish population: results of the Multicenter Polish Population Health Status Study - WOBASZ. Pol Arch Med Wewn. 2011;121(5):156-63.

6. Acton QA. Obesity and diabetes: new insights for the healthcare professional: 2013 Edition. Atlanta: Scholarly Editions; 2013.

7. International Diabetes Federation. Diabetes in Slovakia [Internet]. [cited 2016 Sep 17]. Available from: http://www.idf.org/membership/eur/slovakia.

8. Gavurova B, Soltes, M. System of day surgery in Slovakia: analysis of pediatric day surgery discrepancies in the regions and their importance in strategy of its development. E M Ekon Manag. 2016;19(1):74-92.

9. Šoltés V, Gavurová B. The possibilities of day surgery system development within the health policy in Slovakia. Health Econ Rev. 2014;4:35. doi:10.1186/s13561-014-0035-1.

10. National Health Information Center. Activity of diabetologic clinics in SR 2015 [Internet]. Bratislava: National Health Information Center; 2015 [cited 2016 Sep 16]. Available from: http://www.nczisk.sk/Documents/ publikacie/2015/zs1611.pdf. (In Slovak.)

11. Institute of Health Information and Statistics of the Czech Republic. Activity of diabetology, health care for diabetics in 2013 [Internet]. Prague: IHIS CR; 2015 [cited 2016 Sep 18]. Available from: http://www.uzis.cz/ rychle-informace/cinnost-oboru-diabetologie-pece-diabetiky-roce-2013. (In Czech.)

12. International Diabetes Federation. Diabetes in Czech Republic [Internet]. [cited 2016 Sep 17]. Available from: http://www.idf.org/membership/eur/ czech-republic.

13. International Diabetes Federation. Diabetes in Hungary [Internet]. [cited 2016 Sep 17]. Available from: http://www.idf.org/membership/eur/hungary.

14. International Diabetes Federation. Diabetes in Poland [Internet]. [cited 2016 Sep 17]. Available from: http://www.idf.org/membership/eur/ poland.

15. Roper NA, Bilous RW, Kelly WF, Unwin NC, Connolly VM. Excess mortality in a population with diabetes and the impact of material deprivation: longitudinal, population based study. BMJ. 2001;322(7299):1389-93.

16. Mbanya JC. Healthy ageing in a global world - opportunities and challenges. World Health Day Forum; 2012 Apr 3; Melbourne.

17. Harjutsalo V, Forsblom C, Groop PH. Time trends in mortality in patient with type 1 diabetes: nationwide population based cohort study. BMJ. 2011;343:d5364. doi: 10.1136/bmj.d5364.

18. Kretowski A, Kowalska I, Peczyñska J, Urban M, Green A, Kinalska I. The large increase in incidence of Type I diabetes mellitus in Poland. Diabetologia. 2001;44(Suppl 3):B48-50.

19. Waernbaum I, Blohmé G, Ostman J, Sundkvist G, Eriksson JW, Arnqvist $\mathrm{HJ}$, et al. Excess mortality in incident cases of diabetes mellitus aged 15 to 34 years at diagnosis: a population-based study (DISS) in Sweden. Diabetologia. 2006;49(4):653-9.

20. Vandenheede H, Deboosere P, Espelt A, Bopp M, Borrell C, Costa G, et al. Educational inequalities in diabetes mortality across Europe in the 2000s: the interaction with gender. Int J Public Health. 2015;60(4):40110.

21. Read SH, Kerssens JJ, McAllister DA, Colhoun HM, Fischbacher CM, Lindsay RS, et al. Trends in type 2 diabetes incidence and mortality in Scotland between 2004 and 2013. Diabetologia. 2016;59(10):2106-13.
22. Annandale E. The sociology of health and medicine: a critical introduction. Oxford: Polity; 1998.

23. Choi BC, Shi F. Risk factors for diabetes mellitus by age and sex: results of the National Population Health Survey. Diabetologia. 2001;44(10):122131.

24. World Health Organization. World Diabetes Day [Internet]. 2016 [cited 2016 Nov 17]. Available from: http://www.who.sk/medzinarodny-den/ svetovy-den-diabetu/.

25. International Diabetes Federation. IDF Diabetes atlas - 8th edition [Internet]. Brussels: International Diabetes Federation; 2017 [cited 2017 Nov 17]. Available from: http://www.diabetesatlas.org/.

26. Gulášová I. Obesity as a risk factor. Kompendium medicíny. 2016;(5):735. (In Slovak.)

27. Gavurova B, Vagasova T. Regional differences of standardised mortality rates for ischemic heart diseases in the Slovak Republic for the period 1996-2013 in the context of income inequality. Health Econ Rev. 2016;6(21):21. doi: 10.1186/s13561-016-0099-1.

28. Soltes M, Gavurova B. Quantification and comparison of avoidable mortality - causal relations and modification of concepts. Techn Econ Dev Econ. 2015;21(6):917-38.

29. Shi Z, Zhen S, Zimmet PZ, Zhou Y, Zhou Y, Magliano DJ, et al. Association of impaired fasting glucose, diabetes and dietary patterns with mortality: a 10-year follow-up cohort in Eastern China. Acta Diabetol. 2016;53(5):799-806.

30. Sjöberg L, He L, Kaaja R, Tuomilehto J, Pitkäniemi J. Parity and mortality in cases of childhood-onset diabetes mellitus. Diabetes Metab Res Rev. 2016;32(6):607-14.

31. Wan EYF, Fung CSC, Fong DYT, Lam CLK. Association of variability in hemoglobin A1c with cardiovascular diseases and mortality in Chinese patients with type 2 diabetes mellitus - a retrospective population-based cohort study. J Diabetes Complications. 2016;30(7):1240-47.

32. Campmans-Kuijpers MJ, Sluijs I, Nöthlings U, Freisling H, Overvad K, Boeing $\mathrm{H}$, et al. The association of substituting carbohydrates with total fat and different types of fatty acids with mortality and weight change among diabetes patients. Clin Nutr. 2016;35(5):1096-102.

33. Huang ES, Laiteerapong N, Liu JY, John PM, Moffet HH, Karter AJ. Rates of complications and mortality in older patients with diabetes mellitus: the diabetes and aging study. JAMA Intern Med. 2014;174(2):251-8.

34. Morimoto A, Onda Y, Nishimura R, Sano H, Utsunomiya K, Tajima N; Diabetes Epidemiology Research International (DERI) Mortality Study Group. Cause-specific mortality trends in a nationwide population-based cohort of childhood-onset type 1 diabetes in Japan during 35 years of follow-up: the DERI Mortality Study. Diabetologia. 2013;56(10):2171-5.

35. Liu L. Social connections, diabetes mellitus, and risk of mortality among white and African-American adults aged 70 and older: an eight-year follow-up study. Ann Epidemiol. 2011;21(1):26-33.

36. Feltbower RG, Bodansky HJ, Patterson CC, Parslow RC, Stephenson CR, Reynolds C, et al. Acute complications and drug misuse are important causes of death for children and young adults with type 1 diabetes: results from the Yorkshire register of diabetes in children and young adults. Diabetes Care. 2008;31(5):922-6.

37. Pavkov ME, Bennett PH, Knowler WC, Krakoff J, Sievers ML, Nelson RG. Effect of youth-onset type 2 diabetes mellitus on incidence of endstage renal disease and mortality in young and middle-aged Pima Indians. JAMA. 2006;296(4):421-6.

38. Soedamah-Muthu SS, Fuller J H, Mulnier HE, Raleigh VS, Lawrenson RA, Colhoun HM. All-cause mortality rates in patients with type 1 diabetes mellitus compared with a non-diabetic population from the UK general practice research database, 1992-1999. Diabetologia. 2006;49(4):660-6.

Received January 26, 2017 Accepted in revised form December 19, 2017 